\title{
A figurine from Stare Bielsko. Sexuality in Middle Ages
}

\author{
Arkadiusz Przybyłok \\ Department of Historical Archaeology, Faculty of Philosophy and History, University of Lodz, \\ Uniwersytecka 3, 90-137 Łódź, Poland \\ E-mail address: arkadiuszprzybylok@gmail.com
}

\begin{abstract}
Medieval authorities of the Church unequivocaly condemned sex in its all manifestations. At least, that was their formal stand in this case. Though, relics of the literature, art and archaeology undermine this ,prudish” point of view. A ceramic figurine from late Middle Ages, found in Stare Bielsko, shows a couple that is having sex and can be a good example of not such sanctimonious way of thinking. Originally, the figurine could be a handle of a lid which was glazed green. It seems that figurine's ideological essence is not so far from social standards of decadent Gothic.
\end{abstract}

Keywords: sex; Silesia; pottery; late medieval; figurine; figural art

\section{INTRODUCTION}

By examinating medieval sources word for word, reading another bans, guidebooks for preachers and confessors, considering Middle Ages as devoid of fleshly aspects, boring and unattractive period could be something obvious. But, in that case, we should ask one question: how did medieval people maintained their kind?

Question if sex itself was a sin was not an exact problem in Middle Ages - the real problem they had to consider was if sex in a married life should be permissible. At first, it appeares to be a taboo. But books margins, inculding, of course, church ones, are full of obscene drawings. Just by the side of councillors and good citizens, questioned in municipal documents, we can find also noticed prostitutes and pimps. In the confessors textbooks we can read about weird practises that could be born in shattered minds of monks who had written those books - which sounds even more probable. Nevertheless, I would like to avoid repeated adducing of examples of places where guilds of prostitutes existed or telling about women who put a fish into their vaginas once again, because literature treating about those topics is very abounding [1-2]. However, I would like to focus on some material sign of medieval sexual liberation.

Findings of objects from Middle Ages inspired with sexuality are quite rare. In 1975, during excavations in a settlement in Stare Bielsko (district of Bielko-Biała nowadays) a part of ceramic figurine has been found. This relic (inv. No MC/17/269:75) is a cracked, incomplete figurine carved in a shape of two people lying in a horizontal position, embracing each other (Pic. 1). Its artistic value is rather scant and details are very simplified but it is still 
possible to recognize that the person on the top is a man. He is leaning on his elbows picketed wide apart. Between his legs abnormally huge testicles can be seen - these are the only ones determinants of a sex noticeable on this figurine. Man's feet are made quite ineptly, even in a grotesque way. Whereas, woman's figure is laying supine with her legs parted and bended. It can be that her body was intentionally shaped in socalled hourglass-shape to stress wide hips and breasts. Unfortunately, heads of both figures haven't survived till our times.

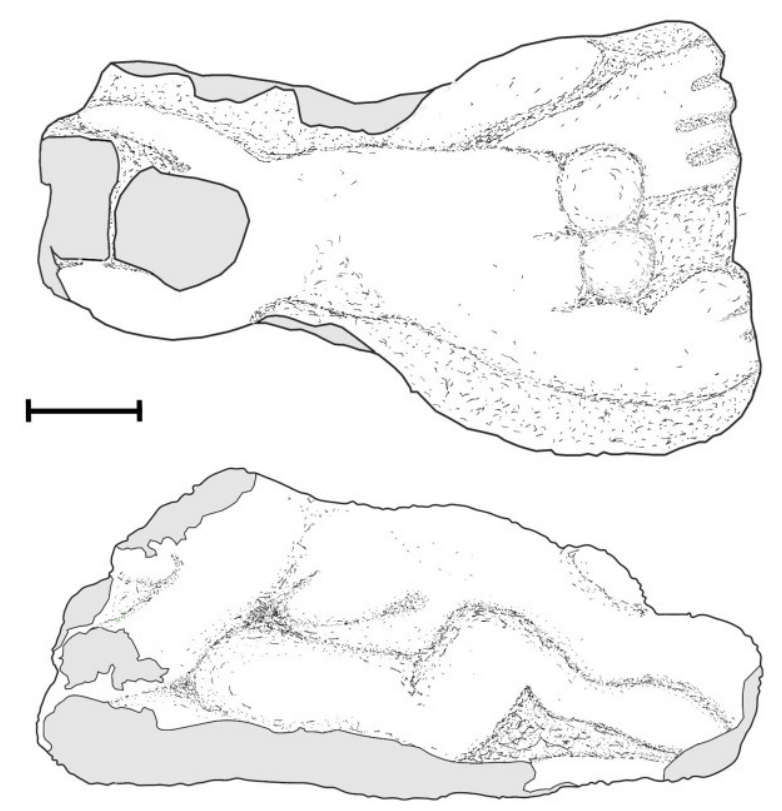

Pic. 1. Figurine from Stare Bielsko.

The representation has been placed on slightly convex clay „plate”, being a part of something bigger. It was made of clay with a lot of fine dash and kilned in a reducing atmosphere to dark grey color which allows to classify it as technological B group of Silesian ceramic [4]. Upper surface of figurine's basis and the figurine's itself have been covered with dark green lead glaze. By observing many cracks and bubbles on it, we can easily guess that the figurine was submitted to too high temperature. Though, absence of burnings and smokes suggests that was a technological error, not repeated baking.

Measurements of the whole relic are not big. It is $62 \mathrm{~mm}$ long, $37 \mathrm{~mm}$ wide and 34 $\mathrm{mm}$ high $-6-7 \mathrm{~mm}$ of this height falls on a thickness of the base.

From time to time, artistic representations can be found on the handles of ceramic aquamaniles or jugs. But in this case, localization of chips on the figurine's basis rim make reconstruction of cosy handle impossible. What is more, vessels like aquamaniles were emocionally and symbolically loaded. Ablution was kind of very lofty action, a part of those made by the lord's table or during religious rituals. That is why I think this bowdy figurine is rather something completely different than an object used to mentioned purposes.

All those remnants of vessel's part which does not exist anymore obstruct localization the figurine on its belly.

There are few questions left to ask: what that erotic carving was, when it was made and if its character was something special. The basis I mentioned before seems to be a clue here. Its edges are plainly chipped - this is simple hint to tell once it was bigger. I suppose that originally it was a lid with a handle carved in more decorative and probably shocking shape 
instead of simple nodular holder. The arrangement of chips can be remnant of the collar (which has not survived), meant to recess it into the vessel's neck.

Lids with collars are known from late Middle Ages to Modern Times. Usually, they are cone-shaped and have simple knob as a handle. When I was looking for analogies, I found only two similar ceramic figural representations from late Middle Ages. First of them comes from Bytom [5] (a figurine without a head), the second, well preserved one - from Jeziorsko [6] (Pic. 2). Both of them were used as lids' handles. The relic from Bytom was made in quite similar technique and style the figures' limbs from Stare Bielsko lid were made, which is remarkable. Distance between those two towns was not so big - this aspect, and striking similarity of both forms, can suggest (but not necessarily) local production method or workshop. The lid from Jeziorsko has a collar which - in my opinion - is a common attribute with Stare Bielsko relic.

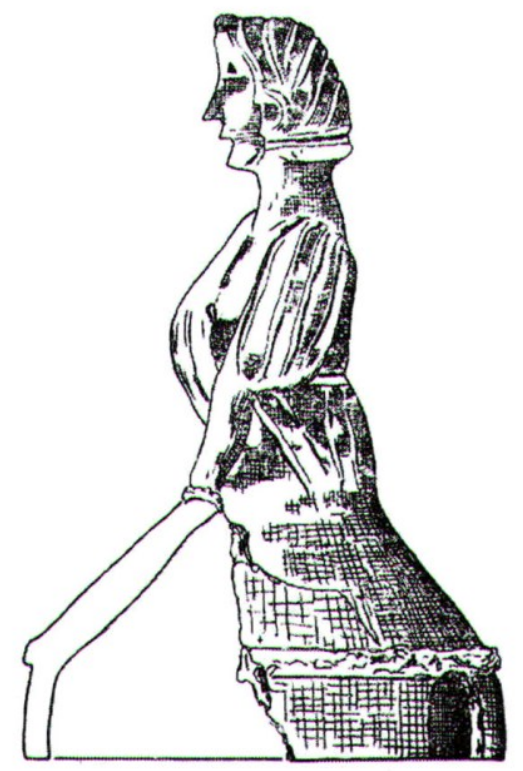

Pic. 2. Lid from Jeziorsko [6].

Dating of the relic from Stare Bielsko presents many problems. I think it is necessary to reject previous thesis about its early-medieval provenence. My first argument against such dating is the technology of work. Group B of Silesian ceramic appeared here in the times of German colonization that had its place at the beginning of the late Middle Ages. In this connection, ceramic objects found next to the figurine should be dated as relics from later, not earlier times as well (Pic. 3). Pots with clear sections with hoods, a jug with funnel-shaped neck decorated with a corrugation [7-8] or dishes included to technological $\mathrm{C}$ group are reasons to believe that the stratum had been formed at the end of Middle Ages. A pavement, also found in this very stratum, is kind of object that, for the most part, appears in neighbouring towns at the beginning of the early modern period [9]. This late dating can be supported also by two mentioned lids from Bytom and Jeziorsko. That is why I would suggest moving Stare Bielsko figurine's dating to $15-16^{\text {th }}$ century and connecting it with later stage of local colonization, maybe even courtly one, instead of early-medieval. 


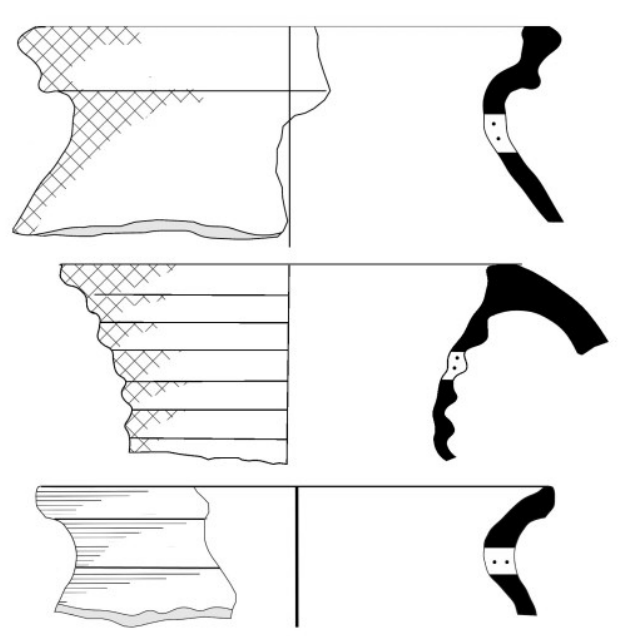

Pic. 3. Pottery from Stare Bielsko.

A cultural context of the figurine is the last issue here worth our consideration. At first glance, the object representing sex scene seems to be something completely incongruous with Middle Ages. But this point of view is typical of our outlook, which has been shaped on romantic images of that epoch. Among all gothic relics many lewd and comic things can be found. For example, we can notice trees hung with penises on the books pages [10] or stoneware vessels from Siegburg decorated with motif of such [11]. It can be assumed that phallic forms were trendy at that time; even a glass found in Elbląg was penis-shaped [12].

Sexual ornaments were very popularly used on small tin badges being found in deposits in medieval towns [11]. There are penises or vulvas with legs, riding horses or having pilgrims attributes. Real, definitely ,serious” badges' versions are reputed to be pilgrims things or early holy medals. But those bawdy ones could have some hidden, not quite devotional meaning.

Another interesting things, but often unappreciated as a source, are stove tiles with erotic scenes on them. A tabular tile covered with green glaze from Banska Bystrzyca (Slovakia) shows a couple that is having sex [13] and is a good example here. Scene's composition is analogous with our lid in spite of the way of forming - the tile is a relief while the figurine's representation is fully plastic.

There is one more relics' type that fits to this erotic trend in carving and other artistic representations: wooden or stone phallic-shaped objects found in early medieval stratums. In spite of their rather schematic form, anatomical shape and size of male penis are accurately resemble. It is not clear what they were used to. They are said to have cult use [14], but I am not very convinced of this theory. We know nothing about medieval ceremonies which required using false penises. At the same time, it is hard to imagine that theoretic cult could expand in such centres as Tum near Łęczyca, Płock or Wrocław which are places where those object were found. Those towns were very important or even principal centres of the state and Church authorities. According to those facts, I would rather incline to suggestion that false penises could be used by ladies for their pleasure while husbands' absence. It is known people of Ancient times made dildos as well; perhaps one day this theory will find its confirmation.

The relic from Stare Bielsko is something very special from one side and perfectly fitted to late-gothinc way of thinking, full of love not only romatnic but lustful as well, from the 
other. It has been created in the reality where brothels existed next to closters walls, prostitutes were participating masses and holy men were writting about raping house stock.

\section{CONCLUSIONS}

All those sexual behaviors known from many writting sources, treated as sinful by the poeple of those days, gather a new meaning nowadays thanks to the archaeological relics. They turn out to be not only fiction, an "urban-legends" written on the margins of a serious treatises. Tinny badges of vulvas, a cup with a penis and a penis-shaped cup or wooden and stone dildos are proofs that medieval life was quite abounding with erotic. Beside those objects, definitely more personal and being used on private or carried under the cloth, there were also articles having more representative purpose (the stove tile and the decorative lid with erotic scene). It is necessary to say that objects connected to that kind of subject-matter and made in this artistic way are relatively rare and were ordered to make other people delighted and jealous at the same time. It is also probable they were some kind of a joke, created at the treshold of a new epoch of humanism.

At the end, I would like to pay some attention to the fact that erotic ornamentation could be something more popular than it seems now (in reference to not big amount of found relics). The figurine from Stare Bielsko has been waiting almost 40 years to be worked up. And, perhaps thanks to the younger generation, who is treating sex as something more normal nowadays, this working up finally happened.

\section{Acknowledgement}

My sincere thanks to the Museum of Śląsk Cieszyński and the Museum of Bielsko-Biała workers, M. Wowra-Płazak, Z. Jagosz-Zarzycka and Mr and Mrs Chorąży, for giving me an access to the finding from Stare Bielsko.

\section{References}

[1] Krawiec A., Seksualność w średniowiecznej Polsce, Wydawnictwo Poznańskie, Poznań 2000.

[2] Le Goff J., Truong N., Historia ciała w średniowieczu. Czytelnik. Warszawa 2006.

[3] Wowra-Plazek M., Karta katalogu naukowego muzealiów archeologicznych no. 1592, typescript, Muzeum w Cieszynie, Cieszyn 1976.

[4] Piekalski J., Płonka T., Wiśniewski A., Badania średniowiecznej posesji przy ul. Nożowniczej 13 we Wrocławiu. Śląskie sprawozdania archeologiczne 32 (1991) 207-238.

[5] Badura B., Wójcik-Kühnel I., Bytom przed wiekami. Muzeum Górnośląskie. Bytom 2004.

[6] Krause E., Średniowieczny gródek rycerski w Jeziorsku koło Turku. Prace i Materiały Muzeum Archeologicznego i Etnograficznego w Łodzi 23 (1976) 293-322.

[7] Kruppe J., Garncarstwo późnośredniowieczne w Polsce. Instytut Historii Kultury Materialnej PAN. Wrocław 1981. 
[8] Niegoda J., Naczynia ceramiczne. In Parcele przy ulicy więziennej 10-11 we Wrocławiu. eds. Buśko C, Piekalski J. Wydawnictwo Uniwersytetu Wrocławskiego. Wrocław 1999. pic. 39.

[9] Buśko C., Archaeologia Historica Polona 5 (1997) 117-132.

[10] Roman de la Rose. Bibliothèque nationale de France. Français 25526. fol. 160r.

[11] Ostkamp S., Journal of Archaeology in the Low Countries 1 (2009) 107-125.

[12] Nawrolska G., A way of life: Luxury in a medieval town. Lübecker Kolloquium zur Stadtarchäologie im Hanseraum 6 (2008) 509-527.

[13] Gruia A., Studia Patzinaka 4 (2007) 85-122.

[14] Wawrzeniuk J., Słowiański domowy kult przodków na tle porównawczym. In Wędrówki rzeczy i idei w średniowieczu, eds. S. Moździoch, Wrocław 2004. 